\title{
KAJIAN ANTITESIS HEGELIAN DALAM ARSITEKTUR
}

\author{
Muhammad Nurwahyu ${ }^{1}$, Murni Rachmawati ${ }^{2}$, Josef Prijotomo ${ }^{3}$ \\ ${ }^{1}$ Mahasiswa Pascasarjana Arsitektur Alur Teori, Sejarah dan Kritik Arsitektur \\ ${ }^{2,3}$ Dosen Jurusan Arsitektur \\ Fakultas Teknik Sipil dan Perencanaan \\ Institut Teknologi Sepuluh Nopember \\ Email: ${ }^{1}$ m.nurwahyu.architects@gmail.com
}

\begin{abstract}
Abstrak
Tulisan ini mencoba mengemukakan keberadaan antitesis Hegelian, yang dapat digunakan sebagai cara berpikir dalam proses perancangan arsitektur. Akan tetapi dengan posisi antitesis yang berada dalam ranah filsafat, maka butuh adanya penyandingan terhadap hal yang serupa dalam arsitektur. Penyandingan dilakukan dengan menggunakan metode kritik deskriptif. Hasil penyandingansimpul ini dapat saja menjadi titik berangkat penggunaan antitesis Hegelian dalam pengembangan rancangan arsitektur.

Dalam penelitian ini antitesis dibuktikan setara dengan architecture of difference sebagai bildung. Kesetaraan tersebut ditunjukkan melalui dialog arsitektur. Dengan kesetaraan tersebut, antitesis menjadi terdefinisi dalam arsitektur dan terjelaskan posisinya dalam arsitektur.
\end{abstract}

Kata kunci: antitesis hegelian, arsitektur, architecture of difference, bildung.

\begin{abstract}
Title: Study of Hegelian Antithesis in Architecture

This paper tries to expose hegelian antithesis existence, that can be used as a way of thinking in architecture design process. With antithesis that lies in philosophy scope, then it needs to be settled with similar thing in architecture. The settlement will be set by using descriptive critique method. The result of the settlement can become a starting point for the usage of Hegelian antithesis in architecture design exploration.

In this paper, antithesis proven to be equal with architecture of difference as bildung. Those equality shown in the architecture dialogue. With this equality, antithesis become defined and known its position in architecture.
\end{abstract}

Keywords: Hegelian antithesis, architecture of difference, bildung.

\section{Pendahuluan}

Georg Wilhelm Friedrich Hegel adalah seorang filsuf besar di era romantisisme Jerman. Karya karya yang dihasilkannya cenderung kontroversial karena seringkali kontradiktif terhadap pemikiran para pemikir besar lain di jamannya. Contoh paling besar adalah saat Hegel membahas manifestasi Immanuel Kant mengenai korelasi realita dengan eksistensi. Kant menyatakan bahwa realita selalu berada di balik wujud eksistensi. Hal tersebut dikritik oleh Hegel dengan menyatakan bahwa realita termanifestasi pada wujud eksistensi dengan dasar pemikiran bahwa 'alasan' adalah yang mendasari keberadaan realita. Dengan diposisikannya alasan sebagai dasar dari penentuan nyata atau tidaknya sesuatu, maka kenyataan adalah segala sesuatu yang rasional. Oleh karenanya 
realita temanfestasi pada wujud eksistensi sebagai yang rasional dan berimbas pada pemahaman bahwa segala hal dalam kehidupan bersifat dinamis (Sorensen, 2003).

Pemikiran Hegel yang seringkali kontradiktif terhadap pemikir lainnya muncul sebagai akibat cara memandangnya yang berbeda dari pemikir lainnya. Dengan dasar ini pulalah ia mencetuskan triadik tesisantitesis-sintesa. Hegel mengemukakan ketiga entitas tersebut sebagai hasil berpikir yang diawali dengan kehadiran tesis. Tesis dianggap sebagai hal yang dinamis sehingga patut diuji yang diwakilkan oleh antitesis. Dari pengujian tersebut, dapat ditarik simpulan lebih lanjut yang berupa sintesa. Triadik ini tidak berhenti pada sintesa karena pemikiran Hegel yang menganggap segala hal dalam kehidupan bersifat dinamis. Dengan begitu sintesa diposisikan kembali sebagai tesis dan proses berulang kembali. Di sini terlihat vitalnya posisi antitesis sebagai entitas yang mampu menjembatani tesis menjadi sintesa (yang diposisikan kembali menjadi tesis kembali). Tanpa adanya antitesis maka tesis menjadi sintesa mutlak yang tidak lagi dinamis.

Sebagai hasil dari filsafat pemikiran, antitesis diharapkan dapat digunakan untuk mengembangkan arsitektur. Dengan pengertian antitesis yang berada pada ruang gerak filsafat pemikiran, maka wajar jika antitesis diharapkan untuk bisa dikembangkan dan digunakan dalam mengkaji, mengapresiasi, bahkan lebih jauh lagi merancang arsitektur. Akan tetapi, perlu adanya penegasan posisi antitesis dalam arsitektur, khususnya berpikir merancang arsitektur. Permasalahan ini merupakan permasalahan yang cenderung bersifat teoritis. Yang dapat dikembangkan lebih luas dan atau mendalam untuk kepentingan perancangan.

Bahasan penelitian ini akan berpusat pada antitesis buah pemikiran Georg Wilhelm Friedrich Hegel yang akan diterjemahkan dalam ranah arsitektur melalui re-intepretasi dari Dennis Hollier (1992). Utamanya dalam dialektika kesadaran yang menjurus pada pemikiran proses malihan tesisantitesis-sintesa. Akan tetapi tidak mengambil pernyataan Hegel dalam membahas arsitektur secara mentah mentah (sebagai hasil pengembangan dari dialektika kesadarannya yang dianggap masuk di dalam ranah arsitektur), karena pemikiran Hegel dalam ranah arsitektur memiliki banyak celah kecerobohan pembahasan sebagai yang non-arsitektural (filsafat dan sejarah). Penelitian ini mencoba memantapkan keberadaan dan posisi antitesis dalam ranah arsitektur.

\section{Metode Penelitian}

Metode yang digunakan dalam penelitian ini merupakan metode kritik deskriptif yang digunakan untuk menemukan sandingan antitesis pada ranah arsitektur. Metode kritik deskriptif dikenalkan oleh Wayne Attoe bersamaan dengan dua kritik lainnya, yakni kritik normatif dan kritik intepretif. Metode kritik deskriptif cenderung memaparkan secara terperinci mengenai pokok bahasan, sedangkan kritik normatif lebih memusatkan perhatian pada aturan, standar, doktrin, sistem yang membantu dalam menjustifikasi suatu hal misalkan justifikasi terhadap estetika sebuah bangunan yang ditinjau melalui aturan golden section. Kritik Intepretif lebih memusatkan perhatian pada upaya menunjukkan kesan, 
pengingat terhadap obyek lain (referensial), pembandingan ataupun penyandingan dengan obyek lain maupun pembelaan bagi obyek kaji terhadap satu pandangan. Dengan kajian penelitian yang memusatkan perhatian pada hal yang masih sangat jarang dikaji, maka digunakan kritik deskriptif sebagai upaya untuk menjabarkan obyek kajian yakni antitesis dalam dialektika Hegelian dalam ranah arsitektur.

Pernyataan-pernyataan Hegel digunakan sebagai dasar berpikir untuk mendekati posisi dan kaidah antitesis yang dimaksud agar kajian tetap berada di jalur yang ilmiah. Hasil kajian tersebut berupa pen-ciri-an yang selanjutnya dicari gayutnya dengan arsitektur melalui peng-analogi-an. Kritik deskriptif yang dilakukan terhadap antitesis Hegelian ini didukung dengan analisa terhadap teksteks pembantu yang merupakan hasil dari kritisi terhadap teks Hegel yang telah dilakukan sebelumnya dan teksteks yang bersentuhan langsung dengan dunia arsitektur. Teks-teks pendukung tersebut sekaligus menjadikan penelitian menjadi lebih terarah dan lebih aktual dibandingkan sekedar menelaah dari tulisan Hegel saja.

\section{Antitesis dalam Dialektika Kesadaran Hegelian}

Proses berpikir manusia tak lepas dari insting kritis. Ilmu pengetahuan yang telah ada tak luput dari insting kritis manusia, utamanya jika terkait dengan sesuatu yang janggal dan dikhawatirkan akan menyesatkan. Dasar berpikir ketakutan akan jatuh pada kesalahan, membuat orang dalam waktu yang bersamaan curiga terhadap ilmu. Maka orang jangan melupakan kemungkinan membalik prosedur ini dengan menempatkan ketidakpercayaan persis dalam ketidakpercayaan ini dan memikirkan pertanyaan lain: Bukankah ketakutan terhadap sebuah kesalahan sudah merupakan sebuah kesalahan itu sendiri? Sebenarnya ketakutan ini mengandaikan sesuatu, sebenarnya banyak sekali, sebanyaknya kebenaran; keragu-raguan dan simpulan-simpulannya didasarkan pada suatu asumsi yang klaimnya terhadap kebenaran belum diuji (Heidegger, 2002).

To liberate ourselves from fear, we realize the fearing outweighs the actual victimization, the actual crime. Ideologies change, can change, are open to resignification.

Epstein dalam Ellin 1995

Oleh karenanya ketika ketakutan tersebut datang, maka dibutuhkan adanya sifat keterbukaan terhadap perubahan paradigma yang selama ini telah melekat dalam diri kita dan orang lain dan hendaknya kita tidak takut dengan perbedaan pemikiran dengan orang lain seperti yang disampaikan oleh Epstein di atas.

Death, if that is what we wish to call this unreality, is the most terrible thing of all and sustaining death's work is what demands the greatest stregth. Impotent beauty detests conceptualisation, because it requires beauty to do thing it is incapable of doing. Now, the life of the spirit is not life that cringes at death and saves itself from destruction, but life that can bear death and is preserved in it. Hegel dalam Hollier, 1992

Dalam bukunya, Hegel mencoba mengemukakan ide pertentangan ekstrim dari fenomena yang terjadi dalam kehidupan. Kematian yang dianggap sebagai hal yang menakutkan bagi mayoritas manusia diusahakan untuk diperlambat, dipungkiri dan 
dihindari. Dan hal ini dirasa naif oleh Hegel. Hingga dia berusaha merealitaskan pola pikir perlawanan manusia terhadap kematian tersebut dengan sekedar memenuhi kualitas hidup yang baik dalam hidupnya, bukan melawan kematian itu sendiri. Sebuah pemikiran yang tidak sematamata kritis, namun dirasionalkan menjadi sebuah logika yang riil, menjauhi absurditas. Pemikiran ini menurut Hegel merupakan gejolak pemikiran dalam kesadaran tertinggi manusia. Pertentangan dengan rasio yang tidak mutlak kebenarannya, akan tetapi dapat menjadi sebuah jalan keluar sebagai alternatif dari konsep yang telah dipahami selama ini.

Dari cara berpikir seperti diatas, muncul pemikiran mengenai antitesis. Menempatkan pemutarbalikan prosedur, menempatkan ketidakpercayaan, memikirkan kemungkinan baru yang mungkin dalam proses berpikir akan mengarahkan kita pada batas kesadaran fenomenal. Batas kesadaran fenomenal ini akan muncul seiring perasaan skeptis yang tidak lain merupakan manifestasi dari rasa putus asa terhadap pemahaman, pengertian, pendapatpendapat normatif dan tanpa menghiraukan apakah itu merupakan pemikiran murninya ataukah telah tersangkut paut dengan pemikiran orang lain (Heidegger, 2002).

Batas kesadaran fenomenal ini akan membantu memunculkan sebuah pranala konsep atau pengetahuan (bukan ilmu pengetahuan). Dimana ketika nantinya diuji diharapkan konsep ini akan memenuhi hasrat untuk mendapatkan sebuah kebenaran yang mana tetap terjadi dualisme. Apakah konsep dalam kesadaran ini akan mengguncang konsep pengetahuan yang telah tertanam dalam benak kita, ataukah kebenaran akan menggubah gugusan konsep pengetahuan dalam alam bawah sadar kita (Heidegger, 2002).

Proses penyusupan konsep kesadaran ini tentunya wajib diikuti oleh pemahaman ke tidak niscayaan akan sesuatu yang absolut dalam pengetahuan, karena akan membelenggu dan menyudutkan kesadaran yang muncul dalam diri kita. Pemahaman ilmu pengetahuan sebagai sebuah media, sebuah instrumen aktif bagi diri kita untuk mencari kebenaran akan mempermudah proses mediasi menuju kebenaran (Heidegger, 2002). Akan tetapi, usaha kritis penyusunan konsep kesadaran menggubah pengetahuan yang ada bukanlah upaya memungkiri yang absolut, akan tetapi menilik dan mengkaji konsep kebenaran yang selama ini telah ada lalu menyandingkan, mengasosiasikan dengan realitas kesadaran yang muncul dalam benak kita. Oleh karenanya jika ilmu pengetahuan digunakan sebagai media aktif untuk menguji sebuah konsep kesadaran, maka akan terjadi proses yang memiliki koridor fleksibel namun sekaligus menjadi titik awal eksplorasi dari konsep kesadaran tersebut. Artinya ilmu pengetahuan akan digunakan sebagai alat uji, yang sekaligus menjadi landasan berpikir ataupun argumen pendukung bagi konsep kesadaran.

"Only that which is simple constitutes a beginning"

Hegel dalam Science of Logic diapdopsi Hollier, 1992

Proses pengujian konsep kesadaran dapat terjadi dan dilakukan apabila diketahui titik awal dari konsep nya secara utuh. Hal ini merupakan sebuah akibat dari konsep kesadaran yang merupakan proses pencarian kebenaran berdasar pada penelusuran origin; 
origin yang dijadikan sebagai hal yang mendasari sebuah ke-berada-an. Hegel melihat absolut sebagai sebuah permulaan yang kompleks, sesuatu yang sebenarnya bisa dipecah dan ditelusuri untuk dicari asal mulanya, wujud origin nya. Untuk mendapatkan sebuah origin, Hegel memandang beberapa aspek yang penting dan berkaitan dengan penelusuran sebuah materi dari non-materi. Aspek-aspek yang dimaksud merupakan aspek kesejarahan, konsep, kronologi, logika, fakta dan hukum yang ada (Hollier, 1992). Dari runtutan kejadian inilah maka muncul antitesis.

Setelah melalui penjabaran singkat mengenai kemunculan antitesis berdasarkan dialektika kesadaran Hegel, lalu apakah definisi antitesis sebenarnya bagi Hegel? Sebelum menjabarkan definisi antitesis menurut Hegel, mari kita tilik definisi dari Hegel menurut intepretasi dari orang lain.

“...2. Pada Fichte dan Hegel "antitesis" merupakan hal kedua dari 3 serangkai (triade), yang melawan tesis. Oposisi dari tesis dan antitesis dipecahkan oleh sintesis, hal ketiga dari tiga serangkai itu"

Bagus, 1996

Menilik dari pendefinisian antitesis di atas, dapat kita ambil sebuah simpulan awal bahwasanya antitesis merupakan satu dari tiga bagian dalam proses triade yang mana akan diakhiri atau disimpulkan melalui sebuah sintesa, dimana antitesis ini dipastikan sebagai bentuk oposisi yang menentang tesis. Akan tetapi jika dikembalikan dari runtutan proses pemikiran Hegel dalam dialektika kesadarannya, definisi tersebut tidaklah sepenuhnya tepat (bagi Hegel). Karena dalam pemikiran Hegel, disebutkan bahwa antitesis juga merupakan sebuah proses memikirkan kemungkinan baru, maka antitesis tidak dimaksudkan untuk semata-mata menjadi oposisi dari tesis - akan tetapi proses penilikan kembali terhadap tesis. Proses penilikan kembali terhadap dasar keberadaan dari sebuah tesis beserta hal yang menyebabkan wujud dari ke-berada-annya. Sehingga dapat ditarik sebuah pendefinisian antitesis menurut Hegel, bahwa antitesis adalah bagian dari proses pemikiran yang mempertanya-kan keberadaan tesis melalui dasar keberadaannya dan aspek-aspek yang menyertainya.

Dari kajian pustaka mengenai antitesis Hegel di atas, dapat diringkas menjadi beberapa pernyataan kunci sebagai berikut:

1. Antitesis merupakan hasil dari proses berpikir yang dilandasi kesadaran manusia dan menyebabkan beda antara obyek satu terhadap obyek lainnya.

2. Antitesis merupakan entitas mandiri di luar tesis yang dapat digunakan sebagai bahan pengujian tesis namun sekaligus juga hasil dari pengembangan tesis.

3. Antitesis akan didapati melalui pemutarbalikan prosedur, menempatkan ketidakpercayaan terhadap keabsolutan dan memikirkan kemungkinan baru.

4. Antitesis adalah hasil dari upaya kritis menanggapi tesis bukan upaya memungkiri tesis, dengan menilik dan mengkaji tesis yang diposisikan sebagai konsep kebenaran yang telah ada, melalui realitas kesadaran yang muncul dalam benak kita. Artinya antitesis tidak semata-mata ditujukan sebagai oposisi dari tesis.

5. Antitesis membutuhkan pengetahuan mengenai origin dari tesis, sehingga antara tesis dan antitesis 
memiliki kesetaraan sebagai syarat dari sebuah dialog untuk mendekati kebenaran.

\section{Antara Beginning dan Origin dalam Arsitektur}

Definisi antitesis merupakan hasil dari tindak mempertanyakan keberadaan tesis melalui dasar keberadaannya dan aspek-aspek yang menyertainya. Perlu diingat juga bahwa antitesis merupakan satu bagian dari sistem triadik yakni tesis-antitesis-sintesa. Jika arsitektur merupakan topik dalam berbicara mengenai antitesis, maka dibutuhkan penjelasan mengenai aspek-aspek penentu dalam menghasilkan antitesis pada topik arsitektur. Dengan demikian antitesis yang sebelumnya berada dalam ranah filsafat dapat digunakan dalam topik bahasan arsitektur.

Dengan diketahuinya antitesis sebagai hasil dari pengembangan tesis bukan sekedar pertentangan dari sebuah tesis, maka selayaknya kita meninjau apakah sebuah antitesis dalam arsitektur dapat hadir tanpa tesis. Jika kita meninjau sebuah antitesis sebagai hasil pengembangan dari sebuah tesis, maka bisa dikatakan bahwa antitesis memiliki perbedaan dan juga kesamaan dengan tesis. Dan bagi tesis, antitesis memiliki hal yang malih dan juga ajek terhadapnya. Malih di sini diartikan berubah dari tesis baik dari segi wujud maupun manifetasi dari wujud, sedangkan ajek diartikan tetap pada kriteria yang dimiliki tesis baik dari segi wujud maupun manifestasi dari wujud tesis. Keajekan ini dikatakan oleh Hegel sebagai origin; sebagai pengikat atau kesamaan antara tesis terhadap antitesis (Hollier 1992). Artinya, origin merupakan hal yang ajek ditemui pada tesis dan antitesis.

Apakah origin dapat disetarakan dengan sebuah beginning? Tentu saja tidak. Jika kita meninjau sebuah beginning sebagai sebuah origin, maka hasil yang didapatkan tentu merupakan perulangan semata. Karena beginning merupakan sebuah entitas mandiri yang memiliki origin sendiri. sehingga dapat dikatakan bahwa sebuah beginning pun memiliki origin. Artinya origin merupakan entitas yang lebih kecil daripada beginning. Jika demikian, maka origin satu arsitektur dengan arsitektur lainnya tidak selalu sama, namun belum tentu juga bertentangan ataupun berbeda.

Dari pernyataan Hollier dalam menanggapi Hegel di atas, maka dapat diringkas menjadi beberapa pernyataan kunci sebagai berikut:

1. Origin merupakan hal tunggal yang ajek ditemui pada tesis dan antitesis.

2. Origin berbeda dari beginning, origin merupakan entitas yang lebih kecil dari beginning.

\section{Dinamika dalam Arsitektur}

Arsitektur merupakan entitas yang gayut dengan fashion. Gayutnya arsitektur terhadap fashion ini menyebabkannya berubah seiring zaman. Akan tetapi perubahan ini bukan hanya pada tampian semata, melainkan konsisten pada tiap elemen arsitektur. Perubahan seiring zaman ini dapat ditinjau pada perkembangan arsitektur mulai zaman neo litikum hingga era arsitektur pasca postmodern kiwari ini. Kebutuhan terhadap perubahan merupakan tuntutan yang sudah sewajarnya dipenuhi dalam segala aspek kehidupan, begitu pula bagi arsitektur.

Perkembangan arsitektur merupakan imbas dari adanya evolusi maupun revolusi pada kehidupan manusia sebagai pengangan, pembuat, pengguna, pemikir maupun penikmat 
arsitektur. Simak saja pada malihnya pandangan arsitektur klasik menuju arsitektur modern. Keberadaan revolusi industri pada sebagian besar wilayah di benua Eropa berimbas pada paradigma ber-arsitektur dari yang simbolik romantik menjadi pragmatik. Lalu dari modern menjadi post modern yang berambisi mengubah pandangan pragmatik dalam arsitektur karena kebosanan. Nature dan nurture manusia menjadi pokok dari perubahan ber-arsitektur yang berimbas pada perubahan arsitektur. Meskipun begitu, pe-langgam-an arsitektur modern maupun klasik ini merupakan satu bentuk tradisi karena sudah berjalan lebih dari satu generasi. Pada tradisi tersebut dapat ditinjau adanya hal-hal yang terulang maupun berubah pada tiap-tiap obyek arsitektur yang ada.

Ignasi de Sola-Morales (1996) mengungkapkan kekagumannya pada arsitektur kontemporer sebagai pendobrak paradigma pengulangan terhadap tradisi arsitektur klasik maupun modern. Tradisi ini diubah dengan tanpa mengindahkan tradisi yang ada sebagai hal baku yang perlu untuk diulang. Akan tetapi ini bukan berarti bahwa arsitetktur yang ada tidak lagi dibutuhkan. Keberadaan arsitektur yang menguikuti tradisi tersebut masih dapat diberlakukan sebagai referensi lintas waktu yang digunakan sebagai pembelajaran.

"Similarly, these architectonic types and models are used to synthesize divergent references to past time." Ignasi de Sola Morales, 1996

Dengan adanya referensi lintas waktu yang telah dihimpun, pengetahuan mengenai tradisi arsitektur yang telah ada dapat dihindari pengulangannya. Pengulangan yang dimaksud tidak serta merta melupakan arsitektur sebagai entitas yang kompleks, yang jika terdapat kerancuan padanya akan dapat menyebabkannya tak lagi menjadi arsitektur. Perlu ada pembatasan pada pembedaan antar entitas, namun sekaligus perlu juga adanya kesetaraan di antaranya. Ignasi de Sola Morales menyampaikan kesetaraan ini sebagai limit.

Limit diungkapkan oleh Ignasi de Sola Morales sebagai berikut:

"The limit exists by virtue of the tension between who wish to instrumentalize it and the indefinite into which it disappears."

Ignasi de Sola Morales, 1996

Keberadaan limit menjadi satu batasan (boundary) yang wajib diulang sebagai satu kebakuan yang mengikat entitas satu dengan yang lainnya sebagai entitas yang sahih sebagai arsitektur. Dengan demikian pembedaan pada arsitektur menjadi lebih berbatas dalam pengertian yang memiliki keterikatan dengan limit tersebut. Limit bagi Ignasi de Sola Morales berada pada ambang antara keberadaan yang padanya dapat diberi instrumentalisasi, dan sekaligus tanpa adanya limit tersebut maka eksistensi entitas yang dimaksud tidak lagi ber-ada. Ini menunjukkan bahwa sebuah entitas dapat saja memuat elemen lain selain limit, namun seketika limit tersebut dihilangkan maka seketika entitas tersebut dapat saja di-mal-intepretasikan sebagai entitas lain. Dengan adanya limit ini maka arsitektur menjadi dinamis dalam ke-arsitekturalannya.

Antitesis dalam Dinamika Arsitektur Antitesis merupakan entitas tunggal hasil dari proses berpikir dialektis. Proses berpikir yang dimaksud adalah siklus berpikir yang berlanjut demi mencapai atau setidaknya mendekati kebenaran. Dalam mendekati 
kebenaran dibutuhkan dialog. Hegel mengkonstruksikan dialog secara lebih sederhana menjadi malihan tiga entitas. Sebuah tesis dikonfrontasi oleh antitesis untuk lebih lanjut digunakan untuk membentuk sintesa. Sintesa ini sendiri nilai kebenarannya sangat mungkin tidak mutlak, akan tetapi setidaknya lebih mendekati kebenaran dibandingkan tesis di awal. Lantas sintesa diposisikan kembali menjadi sebuah tesis yang kemudian dikonfrontasi kembali oleh antitesis dan tahapan tersebut dilakukan kembali secara berkelanjutan sebagaimana di intepretasikan oleh Sorensen, (2003). ${ }^{1}$ Dengan demikian, secara gamblang antitesis merupakan satu entitas pembanding dalam dialog dengan tesis untuk merumuskan sintesa baru. Maka antitesis menjadi entitas tunggal yang berbeda dari tesis.

Dengan sifat tunggalnya, antitesis berbeda terhadap tesis secara signifikan, akan tetapi ada batasan yang harus dimunculkan sebagai kesetaraan dari dua hal tersebut. Tanpa adanya kesetaraan dalam dan di antara keduanya, maka dialog tidak dapat dilakukan. Katakan saja secara sederhana raja tidak dapat berdialog dengan merpati karena keduanya tidak memiliki kesetaraan untuk dapat berdialog, namun seorang raja dapat berdialog dengan punggawa. Keadaan sama sekali berbeda antara kedua entitas tidak dapat diharapkan untuk berdialog.

\footnotetext{
${ }^{1}$ Pendapat Sorensen menjadi penegasan bahwa tidak ada sintesis yang secara murni dan utuh bertahan secara ajek. Sintesis, bagaimanapun dalam dialektika akan menjadi entitas yang tidak stabil dan akan menemui kondisi yang lebih utuh melalui dialog yang berkelanjutan. Lebih rumit dibandingkan dengan yang dikemukakan oleh Hegel.
}

Dialog menjadi hal yang paradox karena entitas yang terlibat diharuskan setara namun berbeda. Artinya butuh adanya batasan untuk menentukan kedua entitas tersebut agar dapat berdialog. Dalam pemikiran Hegel, batasan ini sendiri diwakili oleh origin; sebagai titik berangkat atau asal. Sebagaimana telah dijabarkan sebelumnya bahwa origin berbeda terhadap beginning. Origin lebih berpusat pada pembatasan identikal entitas, bukan representasi maupun manifestasi meskipun dapat terrepresentasi maupun termanifestasi kan. Beginning yang paling sederhana pun, tidak dapat memiliki kesederhanaan yang dapat serta merta digunakan sebagai origin. Artinya beginning bukan merupakan origin meskipun mampu merepresentasikan origin. Origin pada satu entitas berbeda dengan entitas lain. Jika dalam arsitektur, agaknya origin menjadi

Hegel secara serta merta memposisikan simbol sebagai origin akibat kerancuan terhadap pola pikirnya sendiri. Kesadaran dalam memposisikan tujuan dan maksud (means) dan kenyataan pada akhirnya (ends) agaknya dilupakan oleh Hegel. ${ }^{2}$ Semestinya dengan cara berpikir Hegel yang memposisikan realita dan persepsi secara berbeda, sudah seharusnya Hegel menyadari perbedaan antara maksud dan kenyataan pada akhirnya. Jika Hegel menyadari perbedaan ini, maka Hegel akan dapat mengkonstruksikan origin secara konsisten baik dalam maksud dan kenyataan yang terjadi.

\footnotetext{
${ }^{2}$ Hegel yang awalnya memposisikan means sebagai pusat perhatian, membahas dengan menggunakan ends sebagai pusat perhatiannya, yakni arsitektur sebagai tempat manusia berkumpul, sedangkan means menjadi sama sekali dilupakan oleh Hegel.
} 
Pada arsitektur, adanya 'maksud' dan 'kenyataan yang terjadi' menjadi fenomena pembelajaran. Bagaimana tidak, arsitektur yang termanifestasi dalam obyek bisa jadi memiliki 'maksud' dan 'kenyataan yang terjadi' yang sangat berbeda. Perbedaan tersebut bisa jadi menjadikan obyek arsitektur sebagai sebuah kegagalan. Kegagalan ini dapat menjadi sebuah preseden bias antara maksud terhadap kenyataan. Dengan adanya preseden dari beda antara maksud terhadap kenyataan ini lantas arsitektur menjadi entitas yang dinamis, senantiasa mengalami pergerakan. Pergerakan ini sendiri tidak hanya muncul dari pembelajaran terhadap kegagalan, namun juga karena hasrat manusia terhadap inovasi. Dengan munculnya pergerakan dalam arsitektur, lantas menjadikan arsitektur menjadi entitas yang dinamis. Arsitektur wajib berubah jika ada suatu kondisi yang berubah atau muncul gejala baru.

Pada akhirnya simpulannya mengenai origin menjadi bergeser dari fokus bahasan awalnya. Means di sini tidak dimaksudkan sebagai 'cara' karena Hollier memposisikan means dan ends secara linier. Means dianggap sebagai peraduan kepada tuhan sedangkan ends dianggap sebagai tempat berkumpul.

Percontohan dinamika dalam arsitektur ini dapat kita lihat pada munculnya gerakan arsitektur modern yang muncul sebagai respon dari revolusi industri. Dengan demikian arsitektur yang awalnya berdiri dalam lingkup pemikiran klasik yang simbolis dan romantis beringsut secara signifikan menjadi arsitektur modern yang cenderung pragmatis dan ekonomis. Kondisi dinamis yang demikian jika ditinjau dari dialektika Hegel adalah sebuah kewajaran. Kemunculan hal baru sebagai hasil dari pemikiran yang meninjau hal lampau dibandingkan dengan kekinian merupakan sebuah kepastian. Lantas hal baru ini menjadi antitesis dari yang lampau atau yang sudah ada sebelumnya. Kita tidak hanya berbicara mengenai pembedaan langgam -lebih dari itu, identitas antar individu arsitektur sudah sewajarnya berbeda. Lantas mengapa kita perlu meninjaunya dari sudut pandang antitesis Hegel? Karena Hegel memposisikan realita sebagai hal yang dinamis (Sorensen, 2003).

Dengan kepastian bahwa arsitektur adalah hal yang dinamis, maka cara pandang Hegel bersesuaian untuk digunakan dalam meninjau dan merancang arsitektur.

\section{Antitesis dan Dialog Arsitektur}

Arsitektur sebagai entitas yang dinamis secara jelas mengandung perbedaan antara satu sama lain. Dengan kondisi yang demikian maka sudah sepatutnya untuk menemui kesepakatan mengenai "arsitektur" dan "bukan arsitektur" sebagai tolok ukur

kesetaraan dalam dialog. Tanpa adanya kesetaraan, maka tidak akan ada dialog bisa saja yang terjadi adalah epilog maupun sekedar prolog ataupun monolog.

Dalam dialog, yang dibutuhkan adalah pembicara dan lawan bicara. Pembicara bisa dikatakan sebagai yang membuka pembicaraan, sedangkan lawan bicara adalah sebagai yang menanggapi pembicara. Meninjau dari segi waktu, maka pembicara adalah yang lebih dulu melontarkan pernyataan atau pertanyaaan untuk kemudian lawan bicara menanggapinya dan begitu seterusnya. Akan tetapi dalam berdialog, penggal pembicaraan bisa jadi mengalami pergeseran topik sehingga posisi lawan bicara justru 
menjadi pelontar pernyataan atau pertanyaan yang lantas ditanggapi oleh pembicara. Dengan demikian, dalam sebuah dialog antara pembicara dan lawan bicara posisinya bisa jadi bertukar, bergantung pada penggal dialog per topik bahasan.

Begitu pula jika arsitektur diposisikan sebagai sebuah diskursus melalui dialog. Antara pembicara dan lawan bicara butuh dijelaskan entitasnya masing-masing, sehingga dapat terjadi dialog. Jika kita memposisikan antitesis yang masih berada di ranah filsafat secara langsung dalam dialog arsitektur, maka jelas tidak akan ada dialog, yang ada hanyalah dua prolog linear atau epilog pengantar satu sama lain. Maka dibutuhkan tindak penyetaraan antitesis ke dalam ranah arsitektur.

Penyetaraan ini dapat dilakukan dengan meninjau karakter antitesis sebagai lawan bicara dibandingkan dengan perbedaan dalam arsitektur. Sehingga arsitektur di sini ditinjau sebagai konsistensi yang mengalami malihan. Antara arsitektur satu dan lainnya pasti malih karena tiap arsitektur pasti spesifik. Yang tidak spesifik bisa dinyatakan sebagai bukan arsitektur. Malihan sendiri bisa berada dalam rentang waktu maupun jarak. Jika kita meninjau perubahan dalam rentang waktu dan jarak, maka kita meninjau arsitektur layaknya sebuah perjalanan. Dalam sebuah perjalanan, arsitektur mengalami pergeseran-pergeseran menuruti sudut pandang manusia sebagai subyek penentu. Lantas arsitektur yang dilalui menjadi sebuah pelajaran dalam melanjutkan perjalanan. Jika demikian, maka pandangan manusia tak akan sama dari waktu ke waktu, dari tempat satu ke tempat lain.
Snodgrass dan Coyne (2006) menyatakan arsitektur sebagai bildung. Bildung didefinisikan sebagai pematangan diri dalam bahasa jerman. Bildung sendiri merupakan cara terlayak manusia untuk mengembangkan potensi dan kapasitas natural. Pernyataan ini dilandasi oleh pernyataan Hegel yang dikutip oleh Gadamer dalam Snodgrass dan Coyne (2006) berikut:

\section{"When a man gives himself over to work so wholly that it becomes distanced from his personal need and private desires, he not only allows what he makes to assume its own form but does the same to himself. In the selfness of serving, he becomes himself more fully."}

Ide utama pernyataan Hegel adalah bahwa dalam bildung satu entitas menawarkan dirinya pada entitas lain, namun secara bersamaan menjadikan entitas pemberi menjadi lebih menjadi dirinya sendiri. Artinya dengan melepas diri kepada diri lain, kita akan mendapatkan manfaat yakni menjadi lebih utuh. Melepas diri di sini dapat diartikan pergi ke tempat lain yang asing. Dengan proses yang demikian maka arsitektur juga menjadi lebih utuh dengan sendirinya. Dapat dibayangkan bahwa dalam perjalanan arsitektur ini tidak akan ada pemberhentian yang ajek. Yang ada hanyalah tempat pemberhentian sementara layaknya pada stasiun. Perjalanan akan berlanjut untuk menjadikan arsitektur lebih utuh lagi. Inilah sebabnya kita tidak diijinkan untuk berpuas diri pada langgam tertentu. Dengan meng-ajekkan arsitektur pada langgam tertentu, maka arsitektur tak lagi dinamis - tak lagi mendekati keutuhan.

Perjalanan arsitektur untuk mendekati arsitektur yang utuh tak dapat dipungkiri menjadikan arsitektur satu 
dan arsitektur lain sebagai stasiun pemberhentian sementara yang berbeda-beda. Lantas dengan beda ini apakah arsitektur berpaling menjadi arsitektur yang bukan arsitektur? Jika demikian maka perjalanan ini tidak lagi menjadi milik arsitektur, melainkan perjalanan yang bukan arsitektur. Perlu diingat keadaan beda ini harus memiliki satu benang merah yang tebal sebagai yang mempertahankan keberlangsungan dialog. Sehingga jika kita butuh untuk menjadikan individu arsitektur menjadi stasiun pemberhentian sementara, maka kita kita harus mendeskripsikannya tetap sebagai arsitektur, namun berbeda.

Jika kita meninjau perjalanan arsitektur sebagai proses yang menimbulkan beda, maka tentu ada hal ajek hingga menjadikan entitas tersebut tetap arsitektur. Malih dan ajek ini perlu dibatasi, apa-apa yang harus ajek untuk dapat dikatakan sebagai arsitektur dan apa-apa yang dapat dan perlu malih sebagai arsitektur yang bildung. Dengan meninjau malih dan ajek dalam arsitektur ini tampaknya kita dapat merujuk perihal antitesis kepada architecture of repetition and difference dari Ignasi de Sola-Morales.

Arsitektur yang Berbeda sebagai Antitesis dalam Arsitektur

Dalam Sykes (2010), kata antitesis digunakan untuk menimbulkan kesenjangan antara arsitektur seharihari terhadap karya rancang Gehry. Sykes mengutarakan kesenjangan antara arsitektur sehari-hari dengan arsitektur Gehry dari kacamata keseharian yang sifatnya biasa, tipikal dan lokal terhadap yang monumental dan atau ikonik. Dari persepsi yang demikian lantas apakah arsitektur satu sama lain hanya berbeda dalam hal keseharian dan tidaknya? Tentu saja tidak. Pemikiran ini akan menyebabkan keterjebakan terhadap satu pandangan tertentu. Artinya dalam kasus ini seorang arsitek akan terbelenggu hanya pada lokalitas saja. Bisa jadi upaya Gehry yang menghadirkan karakter monumental tersebut justru untuk mengembangkan area lokal di mana rancangannya ditempatkan. Jika demikian, bukankah Gehry justru bersifat loyal terhadap ke-lokal-an tanpa harus terbatas pada yang bersifat lokal? Bagaimanapun, dari pernyataan ini dapat kita lihat bahwa ada beda yang nyata dalam arsitektur. Meski begitu, perbedaan ini tidak muncul secara tiba-tiba dan tanpa prinsip pegangan. Jika semua rancangan dibuat secara semena-mena (arbitrary), maka yang hadir adalah arsitektur tanpa arsitektur, sehingga rancangan tersebut tidak dapat diposisikan sebagai lawan bicara dalam dialog.

Arsitektur yang mengulang dan yang berbeda (architecture of repetition and difference) memberi kesan pertanyaan yang terkait langsung dengan subyek dan kemungkinan ontologi yang mendasari obyek. $^{3}$ Terkait dengan subyek dan ontologi, maka arsitektur perulangan dan perbedaan secara tegas mengungkapkan tautannya dengan cara pikir manusia. Hal ini disebabkan oleh subyek dan dasar ontologi berkutat pada manusia sebagai pelaku aktif dalam menghadirkan kesan dan persepsi, sehingga keaktifan akal pikir manusia menjadi aspek utama yang memberikan penilaian kepada arsitektur entah itu sebagai perulangan atau perbedaan.

\footnotetext{
3 Morales mengarahkan arsitektur sebagai produk dari manusia yang memiliki memori mengenai obyek dan sekaligus memiliki kemampuan mengembangkannya
} 
Dengan dimunculkannya pemikiran architecture of repetition and difference ini maka arsitektur telah dinyatakan sebagai hasil perilaku aktif akal pikir manusia.

Tampak bahwa ada benang merah antara architecture of repetition and difference dengan antitesis sebagai yang sama-sama sebuah hasil dari perilaku aktif akal pikir yang berpotensi besar menimbulkan beda terhadap yang lainnya.

Antitesis dan arsitektur yang berbeda, merupakan sebuah hasil yang jika dikaitkan dengan bildung, maka menjadi hasil yang akan berubah terhadap yang lampau. Bisa juga hasil ini digunakan sebagai titik berangkat baru dibandingkan yang lampau. Namun bisa jadi hanya menjadi pengetahuan sebagai yang harus ditinggalkan. Dengan dinamika yang demikian, maka antitesis maupun arsitektur yang berbeda dapat menjadi tujuan dan sekaligus titik berangkat perubahan pada yang mendatang. Dengan posisinya sebagai tujuan dan sekaligus titik berangkat, maka antitesis dan arsitektur yang berbeda dapat diperlakukan sebagai hal yang signifikan dalam sebuah proses perancangan.

\section{(Bildung)}

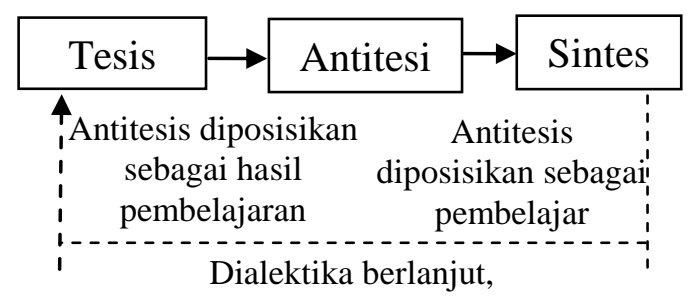

Gambar 1. Antitesis sebagai bildung Sumber: Hasil analisis, 2015

\section{(Bildung)}

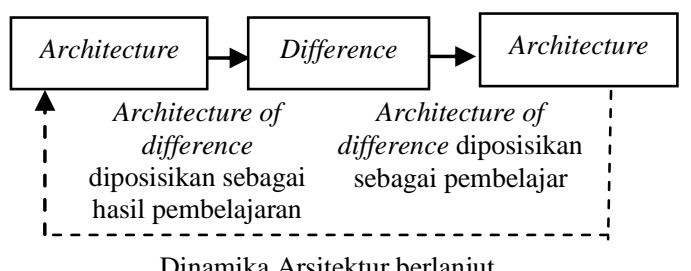

Gambar 2. Architecture of difference sebagai bildung

Sumber: Hasil analisis, 2015

Dalam perihal architecture of repetition and difference, dinyatakan oleh Morales sebagai dua hal yang dibatasi oleh limit atau batas. Batas ini dinyatakan sebagai hal yang tidak dapat dieliminasi. Seketika hal tersebut dieliminasi, maka seketika itu pula obyek dinyatakan sebagai bukan arsitektur. Batas ini sekaligus merupakan inti yang dapat dikembangkan. Dengan adanya batas ini, maka ke depannya ada dua kemungkinan yang muncul; apakah sebuah perancangan akan bertolak pada pengulangan batas dan instrumentasinya, ataukah mengulangi batas dengan merubah instrumentasinya. Dari sinilah muncul dua kategori yang kontras namun ambivalen, seperti mencintai namun sekaligus membenci satu hal.

Dengan batas yang demikian, maka terdapat kesamaan antara batas yang dibicarakan dalam architecture of difference dengan asal usul (origin) yang dibicarakan dalam antitesis Hegel. Keduanya merupakan hal yang tidak dapat di-eliminasi dan sekaligus menjadi inti yang dapat dikembangkan. Dengan kesamaan pada pencirian yang demikian dapatkah diinduksikan menjadi pernyataan bahwa antitesis dalam arsitektur adalah architecture of difference? Jika kita meng-analogi-kan antitesis dengan arsitektur yang 
berbeda (architecture of difference) sebagai hasil pikir dalam dua ranah yang berbeda - arsitektur dan filsafat -, maka kita akan mendapati bahwa keduanya adalah setara. Arsitektur yang berbeda merupakan 'antitesis' yang berada dalam ranah arsitektur.

\section{Kesimpulan}

Arsitektur perbedaan dan antitesis sama-sama merupakan hasil perilaku aktif akal manusia yang berpotensi besar menimbulkan beda terhadap yang lainnya. Dengan diposisikannya arsitektur perbedaan sebagai tujuan sekaligus titik berangkat, maka tampak adanya kesamaan dengan antitesis dalam sebuah bildung. Antitesis menjadi tujuan dan sekaligus titik berangkat. Keduanya dapat menjadi hal yang signifikan dalam proses perancangan. Antitesis dan arsitektur yang berbeda, keduanya perlu dibatasi sebagai upaya mempertahankannya dalam dialog. Antitesis dibatasi oleh origin, sedangkan arsitektur yang berbeda dibatasi oleh limit. Keduanya merupakan dua hal yang sama-sama tidak dapat di-eliminasi dan sekaligus menjadi inti yang dapat dikembangkan. Penelitian ini dapat dikembangkan dan diperdalam terlebih dahulu pada elemen dan aspek-aspek terkait, untuk dapat digunakan sebagai landasan praktis baik dalam mengapresiasi maupun merancang arsitektur.

\section{Terima Kasih}

Kepada Tuhan YME beserta rasul dan tuntunannya yang selalu menjadi pedoman hidup. Papa (alm.) dan mama yang senantiasa mendukung dalam berbagai bentuk untuk menuntut ilmu lebih jauh dan lebih dalam. Kakakkakak yang senantiasa memotivasi dalam segala aspek. Istri yang setia mendampingi dan memberi semangat yang luar biasa. Mertua yang selalu mendoakan dan memberikan dukungannya. Ir. Murni Rachmawati, MT dan Prof. Dr. Ir. Josef Prijotomo, M.Ars yang bersedia dengan ikhlasnya menuntun dalam mengkonstruksikan pemikiran dan memberikan kritik yang membangun dan rekan-rekan Pasca sarjana ITS yang telah menyediakan waktu untuk berbagi pemikiran. Para reviewer (peninjau) dan redaksi yang telah memfasilitasi kehadiran tulisan ini di tengah pembaca.

\section{Daftar Pustaka}

Attoe, W. (1978). Architecture and critical imagination. Cichester: John Wiley and Sons.

Bagus, L. (1996). Kamus filsafat. PT. Jakarta: Gramedia Pustaka Utama.

Benjamin, A. E. (2001). Architectural Philosophy. London: The Athlone Press.

Heidegger, M. (2002). Dialektika kesadaran, perspektif Hegel. Yogyakarta: Ikon Teralitera.

Hollier, D. (1992). Against architecture: The writings of George Bataille. London: The MIT Press.

Kaufmann, W. A. (1996). Hegel: Reinterpretation, texts, and commentary. London: Weidenfeld \& Nicolson.

Morales, I.S., Whiting, S., Thompson, G. (1996). Differences: topographies of contemporary Aachitecture. London: The MIT Press.

Snodgrass, A. dan Coyne, R. (2006). Interpretation in architecture: Design as a way of thinking. Oxon: Routledge. 
Sorensen, R. (2003). A brief history of the paradox and the labyrinths of mind. New York: Oxford University Press.

Sykes, A. K.. (2010). Constructing a new agenda: Architectural theory 1993-2009. New York: Princeton Architectural Press. 